Farum

Sociológico

\section{Forum Sociológico}

Série II

31 | 2017

Transition to work of graduates in Southern Europe:

Crisis and new challenges

\title{
Employability of higher education graduates in Portugal : trends and challenges in the beginning of the 21ST century
}

Inserção profissional de diplomados de ensino superior em Portugal : tendências

e desafios no início do século XXI

Mariana Gaio Alves, César Morais and Miguel Chaves

\section{OpenEdition}

Journals

Electronic version

URL: https://journals.openedition.org/sociologico/1841

DOI: 10.4000/sociologico. 1841

ISSN: 2182-7427

Publisher

CICS.NOVA - Centro Interdisciplinar de Ciências Sociais da Universidade Nova de Lisboa

Electronic reference

Mariana Gaio Alves, César Morais and Miguel Chaves, "Employability of higher education graduates in Portugal : trends and challenges in the beginning of the 21ST century ", Forum Sociológico [Online], 31 । 2017, Online since 31 December 2017, connection on 29 March 2022. URL: http://

journals.openedition.org/sociologico/1841; DOI: https://doi.org/10.4000/sociologico.1841 


\title{
EMPLOYABILITY OF HIGHER EDUCATION GRADUATES IN PORTUGAL: TRENDS AND CHALLENGES IN THE BEGINNING OF THE $21^{\text {ST }}$ CENTURY INSERÇÃO PROFISSIONAL DE DIPLOMADOS DE ENSINO SUPERIOR EM PORTUGAL: TENDÊNCIAS E DESAFIOS NO INÍCIO DO SÉCULO XXI
}

\author{
Mariana Gaio Alves \\ Universidade Nova de Lisboa, Faculdade de Ciências e Tecnologia, UIED - Unidade de Investigação Educação e \\ Desenvolvimento

\section{César Morais} \\ Universidade Nova de Lisboa, Faculdade de Ciências Sociais e Humanas, CICS.NOVA - Centro Interdisciplinar de Ciências \\ Sociais
}

Miguel Chaves

Universidade Nova de Lisboa, Faculdade de Ciências Sociais e Humanas, CICS.NOVA - Centro Interdisciplinar de Ciências Sociais

\begin{abstract}
This paper focuses on the employability of graduates and assuming an approach in which employability is understood as the result of the interaction between higher education and the labour market. This interaction is framed by various factors and variables including the ones related to the characteristics of the social and economic contexts and specific policies. Drawing on statistical data available from Eurostat and OECD the analysis intends to highlight the main trends concerning participation in higher education and involvement of graduates in the labour market in Portugal since the year 2000, taking into account how these trends converge (or not) with the ones observable at European level. Additionally, trends are contextualised in search of possible explanations, namely related to the ongoing global crisis that started in 2008 and to the debt crisis that has contributed to the deterioration of the social and economic situation in the country.
\end{abstract}

Keywords: higher education, labour market, Portugal, Mediterranean Europe

\begin{abstract}
Resumo
Este artigo centra-se na inserção profissional de diplomados, entendida como resultante da interação entre o ensino superior e o mercado de trabalho. Essa interação é condicionada por diversos fatores e variáveis, incluindo os que se relacionam com as características dos contextos sociais e económicos e com políticas específicas. Com base nos dados estatísticos disponíveis no Eurostat e na $O C D E$, a análise destaca as principais tendências relativas à participação no ensino superior e ao envolvimento dos graduados no mercado de trabalho em Portugal desde o ano 2000, tendo em conta a forma como essas tendências convergem (ou não) com as observáveis a nível europeu. Além disso, as tendências identificadas são contextualizadas em busca de possíveis explicações, nomeadamente as relacionadas com a crise global que teve início em 2008, e com a crise da dívida pública que contribuiu para a deterioração da situação social e económica do país.
\end{abstract}

Palavras-chave: ensino superior, mercado de trabalho, Portugal, Europa Mediterrânica 


\section{Introduction}

In this paper we analyse the employability of higher education graduates in Portugal on the basis of one assumption and a hypothesis. The assumption relates to the understanding of employability of graduates as "the result of a complex set of interrelated factors comprising economic and professional contexts, individual trajectories and characteristics, as well as teaching and learning in higher education institutions" (Stiwne and Alves, 2010: 06). Thus, our focus is on the interaction between higher education and labour market within a certain social and economic context characterized by specific policies.

That being so, the hypothesis underlying this paper conveys that the economic and social context has been particularly critical in Portugal, as in other Mediterranean countries, during the beginning of the $21^{\text {st }}$ century, given the ongoing global crisis echoed in 2008, namely as the debt crisis originated the implementation of austerity policies ${ }^{1}$ in the region. Cocozza (2014: 246) argues that "Mediterranean Europe includes Portugal, Spain, Italy and Greece as fully-fledged members" since they share a recent general trend towards the deterioration of social and economic conditions framed by the fact that they represent a case into themselves, due to a number of peculiarities connected to the regulation of the labour market, to educational systems based in universalist principles and to a specific model of welfare system in which family and kindred solidarity networks are highly important.

Therefore, the paper's overall aim is to enable knowledge about the recognisable main trends at national level in Portugal since the year 2000 regarding participation of students in higher education and the graduates' involvement in the labour market, identifying challenges for the employability of graduates. Considering that research about education-work transitions in Portugal is mostly drawing on data collected episodically and locally by universities and research projects, the paper seeks to develop a longitudinal perspective of the main trends in the country that enable the identification of convergences (and divergences) within the European context. That being so, the analysis echoes a long tradition of cross-national comparative research of education-work transitions, that has "documented numerous ways in which processes and outcomes of education-work transitions differ across countries, and it has gone some way towards explaining these differences" (Raffe, 2014: 188).

The research question leading the analysis is the following: to what extent has the national situation been converging (or diverging) from the general situation observable in Europe? Main trends are presented drawing on the statistical data available from Eurostat and OECD and are contextualised in search of possible explanations. The first section of the paper is centred on the participation in higher education and the second focuses on the situation of graduates in the labour market. In the final section, drawing on the analysis underlying the paper, the leading question is answered and possible challenges are outlined.

\section{Participation in higher education: students, graduates and NEET2}

Globally, the number of students participating in higher education in Portugal has been registering ups and downs since the year 2000 (Figure 1). It is also noticeable that women have been the majority among higher education students in Portugal since the beginning of the 21st century and this is in line with the trends visible at the international level (for instance, in 2014 an average of $57 \%$ of first-time tertiary graduates in OECD countries were women, OECD, 2016). Feminization remained sharp throughout the period, although the gap between men and women has softened from the beginning of the century to the middle of the current decade. Accordingly, the decreasing of female students is much more expressive than the reduction of male students since 2000 in Portugal.

In recent years (since 2010/11) there is an observable decrease in enrolments in higher education in the context of the global deterioration of the economic situation that has taken place since 2008 and coexisting with the implementation of severe austerity policies in Portugal dating from the year 2011. The decrease could simply be explained by the fact that the total amount of young people has been diminishing (since the population in the country is ageing), but this sort of explanation is not enough. In fact, from 2001 to 2011 the Portuguese population between the ages of 15 and 29 decreased by $21,3 \%$ but, on the other hand, the enrollment in education increased in all ages (Vieira, Ferreira and Rowland, 2015: 08) and young people tend to stay in the educational system during a longer part of their life-cycles and until they reach higher levels of schooling. That being so, the student population in all levels of schooling increased from 2005 to 2011, without any increase in the figures of population aged 15-24 years in that period.

Additionally, it should be noticed that compulsory education has been extended in Portugal to 12 years of schooling in the year 2009 and consequently a wider group of young people is available to be recruited to enrol in higher education in these last few years. Even if the data is still not available in figure 1 , we know that in the more recent academic years (2015/16, 2016/17 and 2017/18) a slight increase in the number of students enrolling in higher education has been registered. This trend coexists with 
Figure $1 \triangleright$ Students in higher education institutions by sex

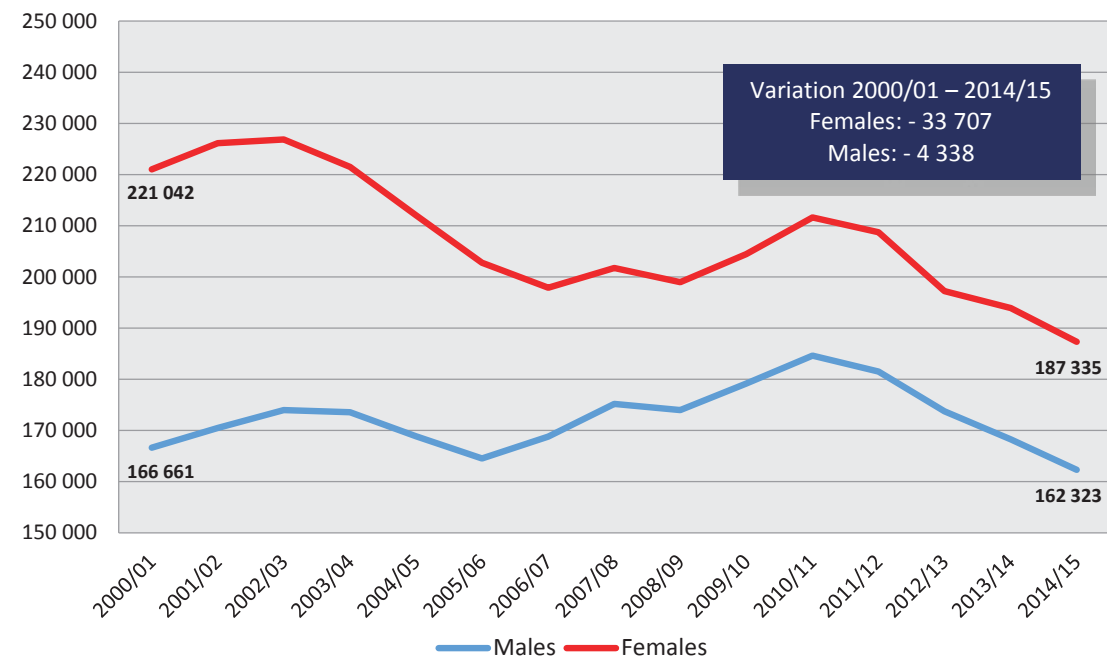

Source: DGEEC/MEC

less severe austerity policies and suggests that the improvement of the social and economic context is linked to small rising in the number of enrolments in higher education.

As mentioned before, a global overview of the evolution in the number of students in higher education reveals a clear increase in the beginning of the $21^{\text {st }}$ century and a succession of decreasing and increasing trends since then. Nevertheless, it is important to emphasise that Portuguese higher education institutions have been graduating a slightly increasing number of graduates since the year 2000 (Figure 2).

Different explanations might contribute to explaining this general trend. One possible expla- nation might be that higher education has been reducing its dropout rates, i.e., the number of students leaving higher education before achieving a degree. Another explanation might be related to the increase of postgraduate rates, i.e., the rising number of students that continue their studies enrolling in a master or other post-graduation degrees immediately after obtaining a first-degree. Finally, the impact of Bologna reform which allows students to finish their graduation in just three years, might account for the rising number of graduates, since before Bologna they would conclude a first-degree typically only after four or five years. Thus, even when the number of students is globally diminishing, the number of graduates is slightly increasing since

Figure $2 \triangleright$ Graduates in higher education institutions by sex

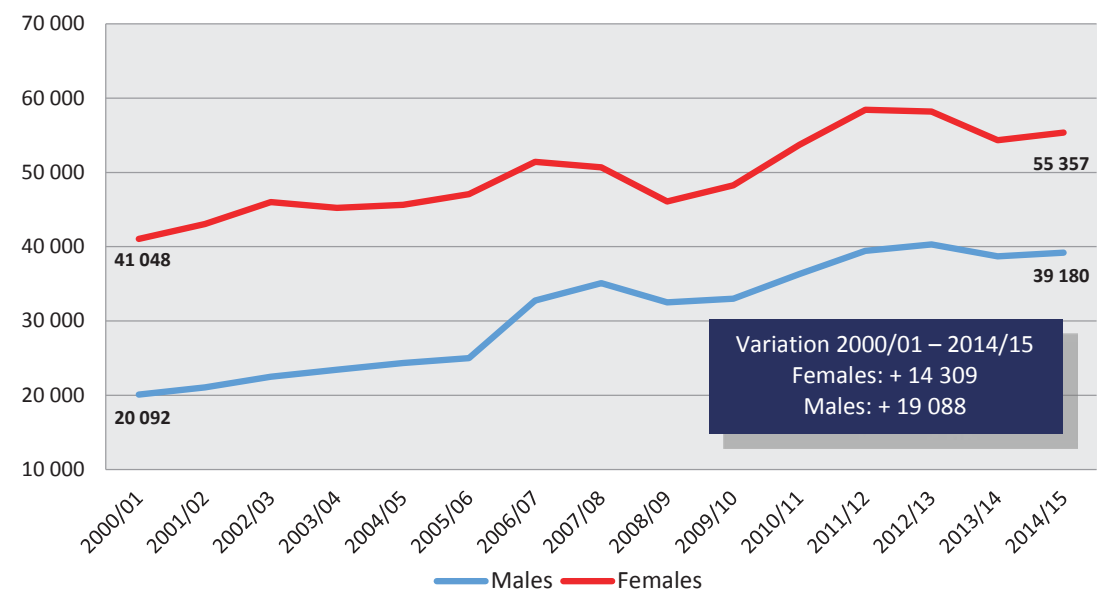

Source: DGEEC/MEC. 
the beginning of the $21^{\text {st }}$ century. Further analysis of the available data will certainly enable us to better understand how the ups and downs in the number of students coexist with the increasing in the number of graduates.

For now, it is important to recall that in Portugal (as well as in other Mediterranean countries) the proportion of higher education graduates within the general population continues to be below the average values registered in Europe. Data from 2015 reveals that in Portugal $23 \%$ of the adults have a higher education degree, the same value being of $35 \%$ in average in the European Union (OECD, 2016). So, the European Union headline target that at least $40 \%$ of the younger generation (adults aged 25 to 34 years old) should have a tertiary degree in 2020 is still to be achieved, requiring the widening of the participation in higher education, particularly in Portugal. In fact, in the European Union there is a noticeable steady growth in average in the number of higher education graduates, even in times of global economic-stagnation, from 24\% of all adults in 2005 to $35 \%$ in 2015 (OECD, 2016). Overall, it seems that in times of austerity the distance between Portugal and the European Union in terms of participation in higher education and total number of graduates in the country has been reinforced.

Another remark to be highlighted when considering figure 2, concerns the unsurprising trend towards women being the majority of higher education graduates in Portugal in every year since the beginning of the $21^{\text {st }}$ century. This trend is not a Portuguese specificity as international data (OECD, 2016) show that women are the majority amongst first-degree and master graduates across the European Union (respectively $60 \%$ and $58 \%$ ) and the OECD countries (correspondingly $58 \%$ and $57 \%$ ). Nevertheless, at the PhD level there are more women graduating (54\%) in Portugal in 2014, but not in average in the European Union (49\%) and OECD (47\%) areas (OECD, 2016).

Even if not completely visible in the data presented, it is also important to stress that since the beginning of the $21^{\text {st }}$ century higher education in Europe has been marked by the changes associated with the Bologna Declaration. The Declaration was signed in 1999 and has been implemented progressively across the countries involved on this process of restructuring higher education. The analysis of the implications of the Bologna process is not the focus of this paper, but it must be highlighted that at least in Portugal this reform demanded a profound transformation within the curricular organization of higher education that affects the value of degrees in the labour market and that transformation was developed in the context of a profound economic crisis that affects the labour market.
About this, research results suggest that doubts arise about the value of the first-degree (that is now typically three years long instead of four or five as it was before Bologna) within the labour market, as well as it seems to be noticeable that the attendance of master degrees has increased significantly (Cardoso et al., 2012). These trends are also illustrated by research focusing on the graduates of a specific university (UNL) ${ }^{3}$ and showing that since 2010 first-degree graduates' employment rates and positions in the labour market degraded more than among master or doctoral graduates and, simultaneously, the number of first degree graduates that have directly proceed to a master degree is increasing (Alves, 2016). Complementary, results from a survey answered by students allow us to conclude that the majority of these students (across gender, study level and institutions) assessed as negative the impact of the Bologna reform in the employability of first-degree graduates, and based on this justified the growing of enrollments at master courses in Portugal since the implementation of the Bologna reform (Sin, Tavares and Amaral, 2016). Hence, the number of master graduates in Portugal increased almost five times between the academic years of 2004/05 and 2009/10 (Alves, 2014: 41).

Nonetheless, higher education graduates tend to be more frequently both employed and involved in education (be it - or not - higher education) throughout their life-cycles. Considering the data about young people neither in employment nor in education and training available since 2004 allow us to conclude that the proportion of NEET amongst higher education graduates is lower than among other graduates with a non-higher education degree (Torres, 2013). However, the analysis of the evolutionary trend since 2004 reveals that the percentage of higher education graduates that are NEET is low but has been steadily increasing, being slightly higher in Portugal particularly since 2011, when considering the average value in the European Union (Figure 3).

On the one hand, the creation of the NEET indicator by international organisations is in itself a good sign of the relevance recognised both to employment and to education and training as dimensions of social inclusion in contemporary societies. In fact, the European priorities for the current decade comprise social cohesion, making lifelong learning an integral part of higher education systems and fostering employability (Stiwne and Alves, 2010).

On the other hand, the rising of the percentage of NEET across all European countries and graduates from every level of education might be understood as a sign that public policies (both at national and European levels) need to develop tools to avoid social exclusion of young adults, aiming at their integration in the labour market, but also at lifelong learning 
Figure $3 \triangleright$ Young people neither in employment nor in education and training (NEET) (\%) - Tertiary education graduates (15 to 29 years)

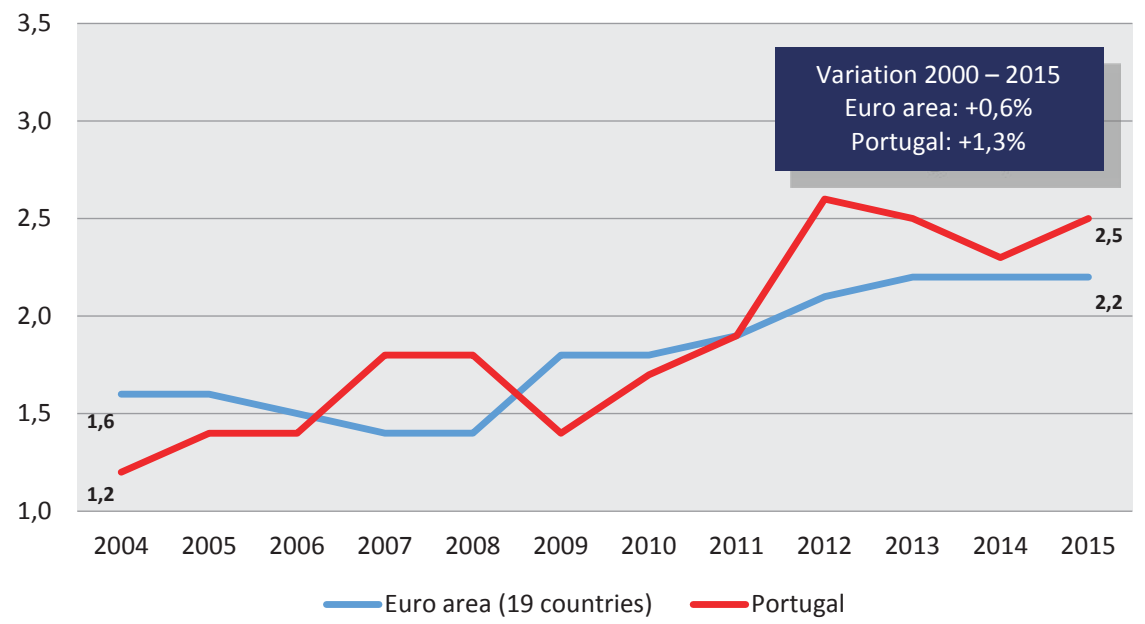

Source: Eurostat.

initiatives that succeed in attracting young people namely throughout the action of higher education institutions. Looking specifically on the situation in Mediterrranean countries, Coccozza (2014) argues that "it appears necessary to adopt job-oriented, integrated-development training programmes, by improving the governance of education-training-work transition processes, by promoting effective lifelong guidance and large-scale operational implementation of so-called "active work policies".

\section{Graduates' situation in the labour market: main trends since 2000}

The first remark about the labour market is to highlight that activity rates of young graduates (aged
15 to 39 years) have been decreasing in Portugal since the year 2000, but have been stable across the European Union across this same phase (Figure 4).

This trend might indicate increasing difficulties for graduates to be part of the active population in the country within the context of a severe social and economic crisis. It should be remarked that lower activity rates coexist with a growth in the number of graduates that continue to study in higher education after completing a first-degree. Namely, this same trend is observable when considering once again the data about UNL's graduates collected in each annual survey since the year 2010 and reinforces the idea that the majority of the first-degree graduates after Bologna continue their academic studies at master levels shortly after graduation (Alves, 2016).

Figure $4 \triangleright$ Activity rates (\%) - Tertiary education graduates (15 to 39 years)

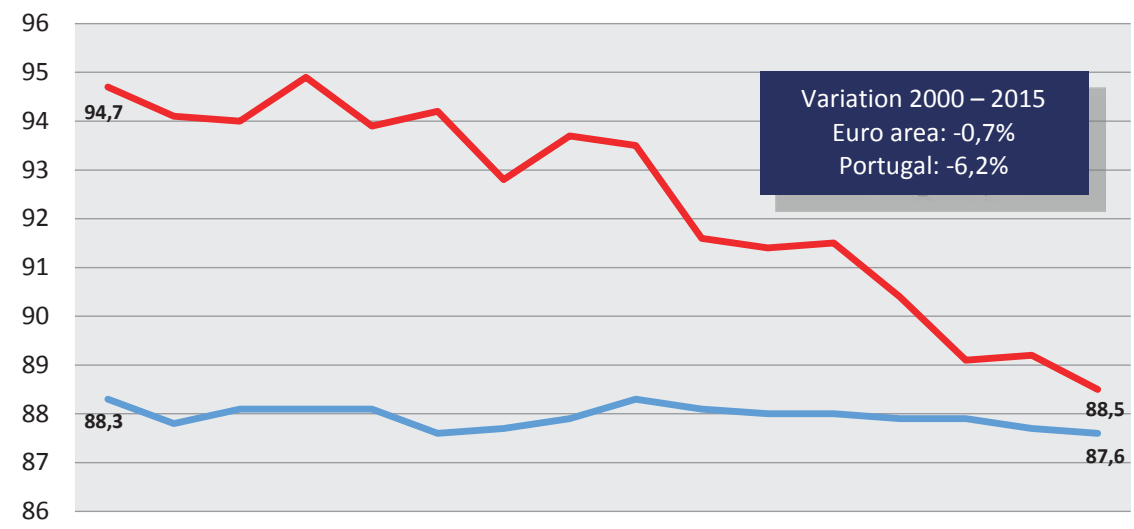

2000200120022003200420052006200720082009201020112012201320142015

Euro area (19 countries) Portugal

Source: Eurostat. 
Furthermore, the significant increase of immigrant Portuguese graduates in the years of economic crisis (Gomes, 2015) also contributes to lower the national activity rate, because the latter only considers the resident population that, throughout emigration, loses economically active individuals.

Regarding gender differences, it must be remarked that women experience lower activity rates across the European Union consistently since the beginning of the $21^{\text {st }}$ century. In Portugal there is a specificity related to the fact that in the year 2000 women with tertiary education experienced lower activity rates than men, but the statistical data indicates that since the year 2009 the activity rates of women have been higher among women than among men. This trend might be explained as a result of the significant increase in the number of women amongst first-degree, master and PhD graduates in Portugal.

Nevertheless, this trend does not imply that women are experiencing better labour market opportunities. For instance, employment rates are higher for men both in Portugal and in Europe in general, suggesting that the feminization of higher education has been resulting in higher activity rates for women, but lower employment rates for women. Research results in various European countries have been highlighting that even if women have succeeded in the educational system by achieving very good academic results, they still occupy less favourable positions in the labour market (Alves and Korhonen, 2016).

The global evolution of graduates' employment rates since the beginning of the $21^{\text {st }}$ century points to a decrease which is particularly pronounced in Portugal when confronted with the average of the
European Union (Figure 5). That said, it is observable that employment rates in Portugal are lower than in the European Union average since the year 2011 , that is even before austerity policies were implemented. From 2013 it is noticeable a slight improvement regarding graduates' employment rates, but its values are still below the ones registered in beginning of the $21^{\text {st }}$ century in the country, as well as below the European Union average values in recent years. To sum up, a particular aggravated deterioration of the employment situation of higher education graduates is observable in Portugal when compared to the European Union, coexisting with the global crisis that started in 2008 and with the debt crisis in the country.

Data about temporary employees, mean income and occupation adjustment are taken into consideration aiming at contributing to the evaluation of the quality of the employment and not only its quantity (viewed throughout the activity and employment rates).

About temporary employees ${ }^{4}$ it is necessary to stress that this type of job has been quite significant in Portugal during the first 15 years of the $21^{\text {st }}$ century, assuming a much wider proportion than in average in the European Union (Figure 6). Accordingly, other researchers have suggested that Portugal is one of the countries in Europe, together with Poland and Spain, in which the proportion of temporary employees is higher; as well as it is one of the countries where this proportion has been more visibly increasing in the last 20 years in all age groups (Oliveira and Carvalho, 2008). This might be interpreted as part of a wider and structural change towards the liberalisation of labour markets in which the case of Portugal is representative of countries in

Figure $5 \triangleright$ Employment rates (\%) - Tertiary education graduates (15 to 39 years)

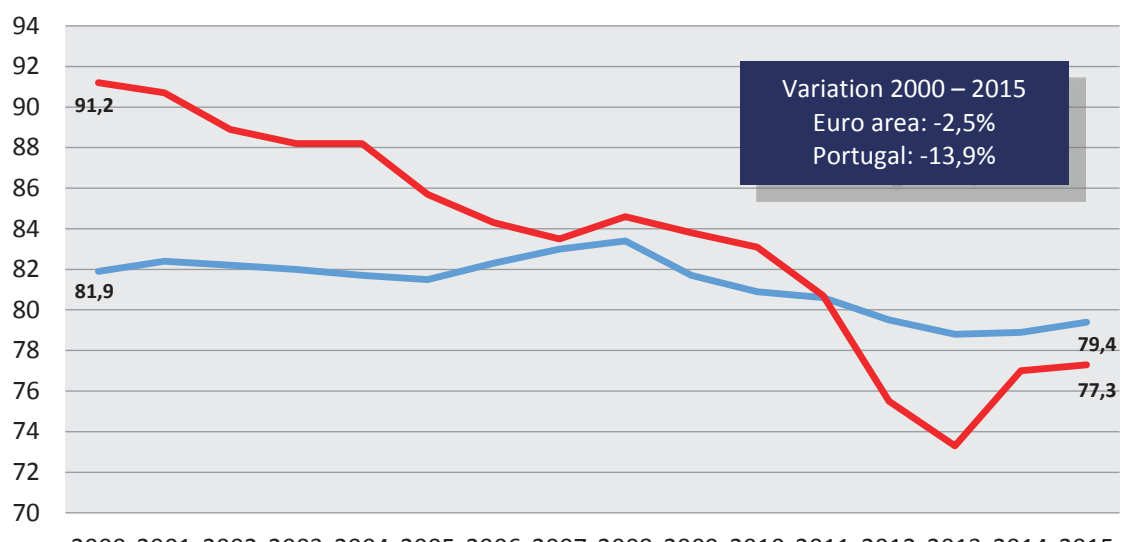

2000200120022003200420052006200720082009201020112012201320142015

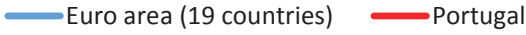

Source: Eurostat. 
which barriers to dismissing permanent employees are significant, thus leading employers to frequently choose to hire temporary employees (Oliveira and Carvalho, 2008).

It is worth noticing that the slight decrease since 2009 in the number of temporary employees might be due to their flexible and non-permanent work contracts that, in times of economic crisis, make temporary employees easier to dismiss by employers (whether private or public). This trend towards the decreasing of temporary employees tends to be reversed from 2014 and further analysis should enlighten whether jobs recently occupied by higher education graduates in Portugal are mainly temporary. In fact, the majority of active measures of employment undertaken by the Portuguese State aimed at unemployed young graduates have been directed to the promotion of jobs of limited duration - internships placements - that, inevitably, increases the number of temporary workers among this population (Valadas, 2013). Consequently, considering the 19 countries included in the Euro Area, Portugal accounts for the largest share of temporary workers among tertiary graduates aged between 15 and 39 years in $2015^{5}$.

Regarding gender differentiation, it must be signalled that both in Portugal and in the European Union in average there are more women than men among those working as temporary employees. In Portugal, this gender gap might be related to the overrepresentation of women in the services sector, precisely where non-permanent hiring is more frequent (Casaca, 2012). Nonetheless, it must be underlined that temporary workers figures increased more among men during the years of economic crisis, thus closing the gender gap (Ferreira, 2014).
Differently from the previous presented information, the data available concerning income considers only the last 10 years and adults of all ages (from 18 to 64 years). It is noticeable a divergence between the mean income values: the values have been decreasing in Portugal meaning that graduates earn less than they used to, but these same values remain stable within the European Union area (Figure 7).

Briefly, the data suggests that graduates in Portugal have a progressive lower net income, which is not surprising given both that taxes were significantly increased in the last few years in the country and that all state employees have had severe cuts in their salaries since 2011. Drawing again on the data collected at UNL to complement the analysis, it looks as if the situation in the public sector is particularly relevant for higher education graduates' situation in the labour market since the major part of higher education graduates are employed by the state and this is particularly true for master and PhD (Alves, 2016). Additionally, it is important to consider that, in the Euro Area, the biggest reductions in the annual income of higher education graduates between 2011 and 2015 were in countries that have also experienced austerity policies (namely, Cyprus, Greece and Spain), while most of the other countries registered an increase in the mean equalized net income of graduates.

The information about occupation adjustment is also considering all adults since the year 2000 (Figure 8$)^{6}$. Current discourses often emphasize that labour market difficulties experienced by graduates might be explained, at least partially, throughout eventual (dis)adjustment of higher education credentials. Nevertheless, the observation of figure 8 indicates that the levels of occupation adjustment have been slightly reduced, but even

Figure $6 \triangleright$ Temporary employees (\%) - Tertiary education graduates (15 to 39 years)

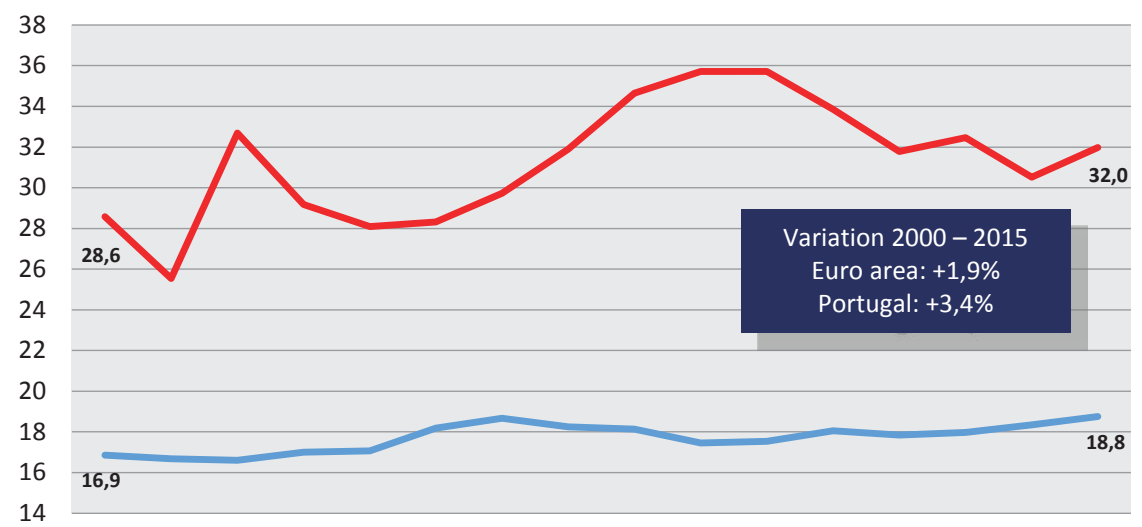

2000200120022003200420052006200720082009201020112012201320142015

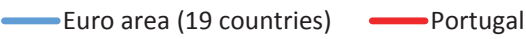

Source: Eurostat. 
Figure $7 \triangleright$ Mean equalized net income (Annual $€$ ) - Tertiary education graduates (18 to 64 years)

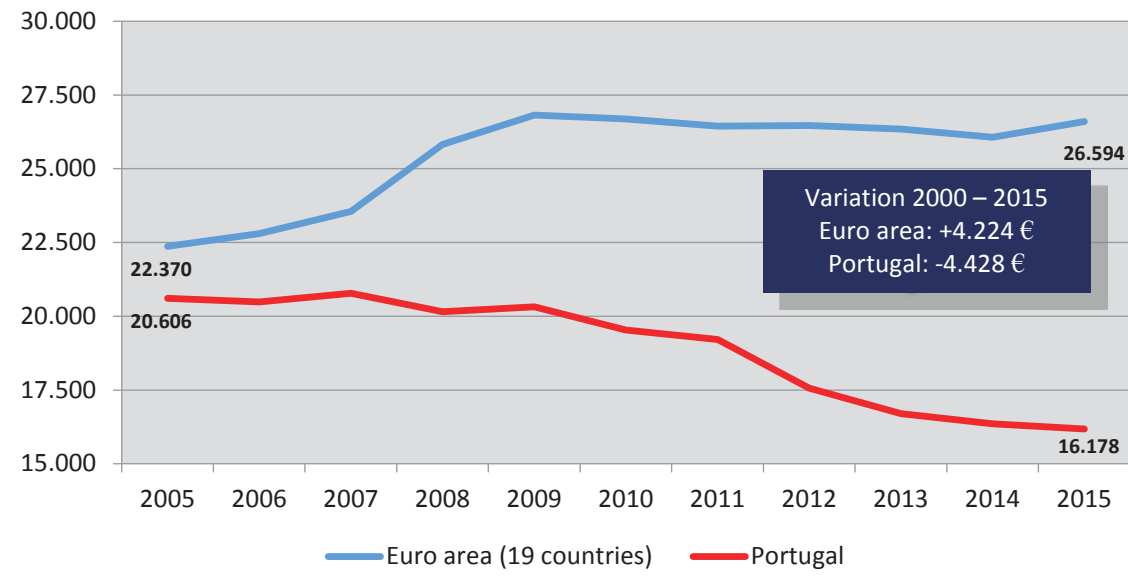

Source: Eurostat.

Figure $8 \triangleright$ Occupations adjusted to tertiary education graduates (\%) - Tertiary education graduates (15 to 65 years)

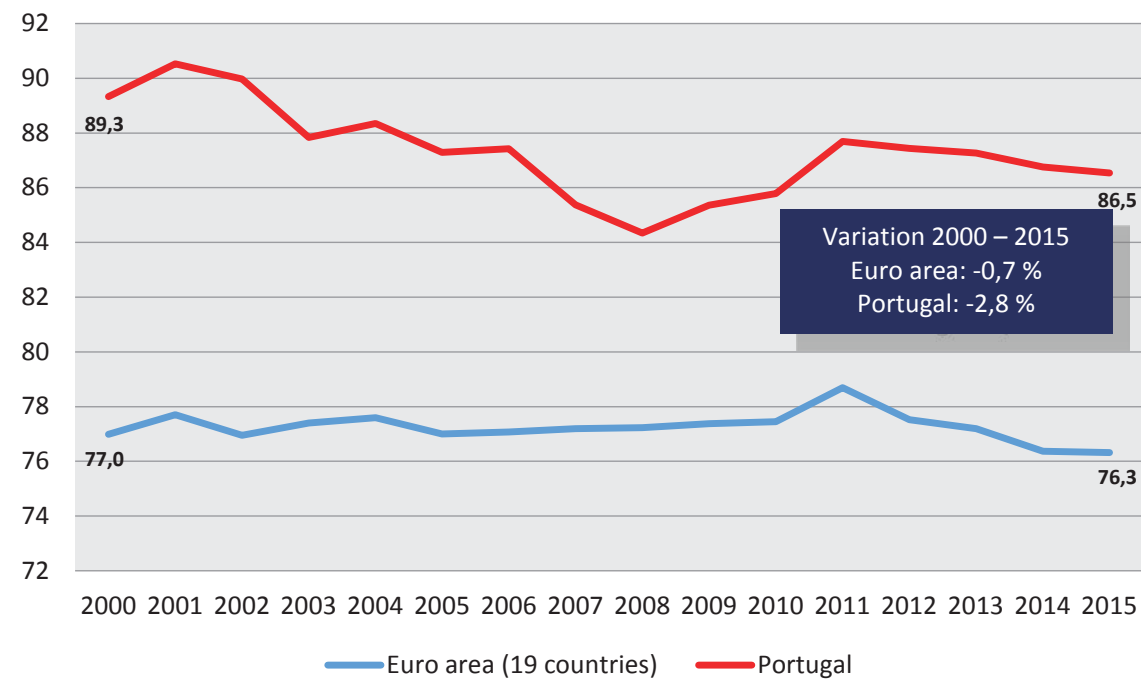

Source: Eurostat.

so, interestingly, they do not seem, to be a problem, especially in Portugal when compared to the European Union average.

So, it is suggested that (dis)adjustment between educational credential and labour market occupations cannot easily and straightforward be pointed out as an explanation for the worsening of graduates' work conditions related to employment/unemployment, temporary jobs or mean income. To reinforce this hypothesis, it should be remarked that research conducted at UNL focusing recent graduates' views reveals that these graduates evaluate their learning experience in higher education quite positively, as well as (mis)adjustement does not seem to be a problem according to their perspective ${ }^{7}$, but transitions between education and the world of work have undoubtedly become more complex and precarious. Even if further exploration of the data and deeper research on this topic are needed, this assertion seems to have grounds and illustrates the current complexity of the interaction between education and work as is framed by a diversity of factors and variables.

Regarding gender differences, it is possible to highlight that less women than men experience occupation adjustment both in the Portuguese case and in Europe in general since the year 2000. Similarly to the information about employment rates, temporary jobs and mean income, the information about occupation adjustment also conveys the idea that among higher education graduates women experience more difficulties in the labour market 
than their counterparts, being more willing to accept a job that does not correspond so accurately to their academic training.

Although the data here presented shows that the situation of the labour market has worsened significantly in Portugal within the context of the economic crisis and of the implementation of austerity policies, it must not be forgotten that higher education graduates do have better working and employment conditions than those not possessing a higher education credential. This is true for Europe in general, as well as in the Portuguese case (OECD, 2016).

Nonetheless, the trends identified have created a favorable context for the emigration of Portuguese graduates and, so, the number of emigrants has doubled during the period 2010-2013 with a growing proportion of higher education graduates choosing to live and work in other European countries from which the United Kingdom used to attract a higher number of preferences (Gomes, 2015). The main reasons for this Portuguese "brain drain" are professional (better career progression and professional self-realization) and economic (better employment rates and wages), and almost half of the highly-qualified Portuguese emigrants consider to stay abroad more than 10 years or even all their life, especially if the prospects of career progression in the country of origin remain limited due to the economic crisis (Gomes, 2015).

\section{Conclusion}

The analysis of statistical data within this paper enables us to sketch the main trends regarding the employability of higher education graduates in Portugal since the year 2000, highlighting a part of the complex set of interrelated factors that frame the transitions education-work. In this final section answers to the leading research question are outlined, as we identify points of convergence (and of divergence) when confronting the Portuguese situation and the general trends observable in Europe.

Regarding participation in higher education it is remarkable that even if the number of students has been diminishing, a clear increase in the number of graduates is observable in Portugal across the beginning of the $21^{\text {st }}$ century. The growing proportion of adults with a higher education degree in the country is a trend in agreement with the situation in other countries whether in Europe or in other regions of the world. However, the participation in higher education in Portugal is still below the average values registered in the European Union and distant from the benchmarks established for 2020 by the European Commission. This situation might hinder possible future scenarios as education is, in today's knowledge societies, not only a central element for economic development, but also increasingly valued in terms of social cohesion and democracy (Cocozza, 2014). Within this context, challenges faced by higher education comprise the promotion of its social dimension and making lifelong learning a part of higher education systems, as well as fostering employability (Stiwne and Alves, 2010), and have become paramount in the $21^{\text {st }}$ century. In fact, the relevance of these challenges is reinforced when recalling that the percentage of NEET has been increasing during the last decade and is especially high in Portugal.

A global overview of the indicators related to involvement in the labour market reveals a deterioration of the situation for higher education graduates in Portugal during the beginning of the $21^{\text {st }}$ century. This is quite evident when looking at the significant reduction in activity and employment rates, as well as at the decrease of the average income. Additionally, a persistent high proportion of temporary employees remains a trend during the last 15 years in the specific case of Portugal and features an important challenge since research results suggest that this characteristic might lead to weaker social cohesion (Kalleberg, 2009; Scherer, 2009). Regarding gender, it must be pointed out that feminization of higher education students and graduates is a general trend, even more pronounced in Portugal where it reaches the PhD level. Nonetheless, it is also a convergent trend that the situation of women in the labour market is not more favorable than the one of men in different countries. This denotes that graduates do experience transitions from education to work differently according to their gender and other social and personal characteristics.

Overall, the Portuguese situation probably presents similarities regarding other Mediterranean countries where the ongoing crisis that begun in 2008 has also been impacting negatively in almost all indicators (Cocozza, 2014). Nevertheless, it must be detailed that activity and employment rates of higher education graduates in Portugal used to be higher than the European average and are now more alike, whereas mean income is much more reduced and the proportion of temporary employees remains extremely high. Within this global context, the emigration of Portuguese graduates has been rising and implies a diminishing contribution of individuals throughout taxes and payments to the social security and welfare state. This also could mean that the country might lack qualified workers to develop certain economical dynamics resulting in a waste of talent and investment. Thus, reflection is needed about the national and European policies that might better help to face and get over this sort of scenarios and situations.

These policies need to be designed considering the diversity of factors and variables that frame 
the interaction between higher education and the labour market and, consequently, the employability of graduates. The main assumption underlying this paper, as stated in the introduction, is that there are no direct links between higher education credentials and jobs in the labour market. In fact, research on the employability of higher education graduates has been supporting that a higher education degree is a necessary credential to enter the labour market, but is not sufficient in ensuring protection against unemployment and growing employment difficulties.

That being so, the growing troubles experienced by graduates in entering the labour market has been stimulating changes in higher education institutions, frequently determined by the intention to provide students with the skills and knowledge better adjusted to their labour market occupations. Even if these changes might be quite positive for students, it is important to remember that it is not possible to aim at a perfect match between academic education and professional activity of graduates, and that higher education cannot be reduced to an agency for the training of professionals. In fact, the missions of higher education not only have included the preparation for professional activities since its origins in the medieval ages, but also comprise other aspects such as educating citizens and promoting social, cultural and scientific development.

Additionally, in the Portuguese case there is evidence that the adjustment between educational credentials and occupations does not seem to be a problem, suggesting that changes in higher education institutions and their curriculum are is not sufficient to face the worsening work and employment conditions. On the one hand, "a dimension of structural reform of the economic, social and educational system, in such a way as to guide an integrated economic and labor development policy, in the direction of social inclusion" (Cocozza, 2014: 254) should be considered particularly in Mediterranean countries. On the other hand, it is essential to avoid viewing the learning in higher education as a response to the needs and demands identified in the labour market, as well as the existing idea that employability should be the main criterion to evaluate higher education systems, institutions and degrees needs to be openly and deeply questioned.

Globally, this paper reinforces the idea that the patterns of transition between higher education and the labour market have been changing and becoming more diverse, complex, precarious and individualised, as highlighted by various researchers (Alves, 2009; Alves and Korhonen, 2016; Chaves, Morais and Nunes 2009; Ramos, Parente, and Santos, 2014). Thus, a set of questions arises centred on the possible challenges related to the increasing plurality and precariousness of transition trajectories experienced by graduates regarding expectations, aspirations and values linked to higher education and the world of work. Is there a trend towards individualisation in both education and work that threatens societies? If so, how can higher education contribute to foster employability as well as to enhance civic participation and social cohesion? Answers to these questions demand further research work and deeper knowledge about graduates' transitions between higher education and the world of work.

\section{Notas}

1 The term "austerity policies" refers to a set of government measures triggered in the context of the recent crisis with the intention of containing the public expense through reductions in public investment and social protection. In the Portuguese case, austerity policies had negative impacts on the labour market, namely increasing the levels of inactivity and unemployment (Costa and Caldas, 2013).

2 NEET is the acronym for people that are "Not in Education, Employment or Training".

3 The option to draw on data about UNL's graduates is based on the recognition that it is the only higher education institution in Portugal in which it is possible to compare and consider jointly first-degree, master and $\mathrm{PhD}$ graduates in a longitudinal perspective since the year 2010. This is because the Observatory of Graduates Transitions to Work (OBIPNOVA) at Universidade Nova de Lisboa (UNL) carries out an annual survey since 2010 to representative samples of first-degree, master and $\mathrm{PhD}$ graduates that have finished their studies from UNL one year before, ensuring the comparability of the results obtained in each year and for each of the groups of graduates.

4 According to Eurostat definition, employees with temporary contracts are those who declare themselves as having a fixed term employment contract or a job which will terminate if certain objective criteria are met, such as completion of an assignment or return of the employee who was temporarily replaced.

5 If we place the countries in descending order: Portugal $(32,0 \%)$, Spain $(28,7 \%)$, Slovenia $(21,5 \%)$, Netherlands $(20,6 \%)$, Italy $(19,6 \%)$, Finland $(19,6 \%)$, France $(18,7 \%)$, Cyprus $(18,3 \%)$, Germany $(17,2 \%)$, Luxembourg $(12,8 \%)$, Austria $(12,1 \%)$, Belgium $(12,0 \%)$, Greece $(10,7 \%)$, Ireland $(8,3 \%)$, Slovakia $(7,1 \%)$, Malta $(6,6 \%)$, Estonia $(3,3 \%)$ and Latvia $(2,5 \%)$ - no data is available for the case of Lithuania.

6 In order to calculate the occupation adjustment, we follow the Eurostat criterion, where it is assumed that the first three professional categories of ISCO 08 - "Managers", "Professionals" and "Technicians and associate professionals" - are adjusted for higher education graduates. (Rademacher and Leitner, 2009: 132).

7 In the data annually collected by ObipNOVA it is noticeable that, since 2010, the vast majority of UNL graduates would repeat the same course and choose the same university at the time of the inquiry. It is also noteworthy that the majority evaluates positively the adjustment of their professional activity to the scientific area of formation -6 or more points in a scale between 1 and 10 . These conclusions are valid for first-degree, master and doctoral graduates. 


\section{References}

ALVES, M. G. (2016), "Transições entre educação e trabalho: os diplomados da UNL antes e depois de Bolonha", Revista APSIOT, (41/42), pp. 91-102.

ALVES, M. G. and V. Korhonen (2016), "Transitions and Trajectories from Higher Education to Work and Back - A Comparison between Finnish and Portuguese Graduates", European Educational Research Journal, 15(6), pp. 676-695.

ALVES, N. A. (2009), Inserção profissional e formas identitárias, Lisboa, Educa.

ALVES, N. A. (2014), "O desenvolvimento do ensino superior em Portugal: a década de 2000-2010", in A. Costa, J. Lopes and A. Caetano (orgs.), Percursos de estudantes no ensino superior: fatores e processos de sucesso e insucesso, Lisboa, CIES/ /ISCTE, pp. 33-49.

CARDOSO, J.; V. Escária; V. Ferreira; P. Madruga e M. Varanda (2012), Empregabilidade e ensino superior em Portugal (A3ES Readings N.o 3), Lisboa, A3ES.

CASACA, S. (2012), "Mercado de trabalho, flexibilidade e relações de género: tendências recentes", in S. Casaca (ed.), Mudanças laborais e relações de género. Novos vetores de desigualdade, Lisboa, Almedina, pp. 09-50.

CHAVES, M.; C. Morais e J. S. Nunes (2009), "Os diplomados do ensino superior perante o mercado de trabalho: velhas teses catastrofistas, aquisições recentes", Forum Sociológico, (19), pp. 83-98.

CocozZA, A. (2014), "Labour-Market, Education and Lifelong Guidance in the European Mediterranean Countries", Italian Journal of Sociology of Education, 6(3), pp. 244-269.

COSTA, A. e J. C. Caldas (2013), "A União Europeia e Portugal entre os resgates bancários e a austeridade: um mapa das políticas e das medidas", A anatomia da crise (1.0 Relatório, preliminar), Lisboa, OCA, pp. 72-107.

FERREIRA, V. (2014), "Employment and Austerity: Changing Welfare and Gender Regimes in Portugal", in M. Karamessini and J. Rubery (eds.), Women and Austerity. The Economic Crisis and the Future of Gender Equality, Londres, Routledge, pp. 207-227.

GOMES, R. (2015), Fuga de cérebros, Lisboa, Bertrand.
KALLEBERG, A. (2009), "Precarious Work, Insecure Workers: Employment Relations in Transition", American Sociological Review, 74(1), pp. $1-22$.

OECD (2016), Education at a Glance 2016: OECD Indicators, OECD Publishing, Paris. Retrieved from http://dx.doi.org/10.187/eag-2016-en

OLIVEIRA, L. and H. Carvalho (2008), "A precarização do emprego na Europa", DADOS - Revista de Ciências Sociais, 51(3), pp. 541-567.

RADEMACHER, W. and M. Leitner (2009), Bologna Process in Higher Education in Europe, Luxemburgo, EC.

RAFFE, D. (2014), "Explaining National Differences in Education-work Transitions", European Societies, 16(2), pp. 175-193.

RAMOS, M.; C. Parente e M. Santos (2014), "Os licenciados em Portugal: uma tipificação de perfis de inserção profissional", Educação e Pesquisa, 40(2), pp. 383-400.

SCHERER, S. (2009), "The Social Consequences of Insecure Jobs", Social Indicators Research, 93(3), pp. 527-547.

SIN, C.; O. Tavares and A. Amaral (2016), "Student Perceptions of the Employability of the First Degree in Portugal", Education + Training, 58(9), pp. 966-998.

STIWNE, E. and M. G. Alves (2010), "Higher Education and Employability of Graduates: Will Bologna Make a Difference?", European Educational Research Journal, 9(1), pp. 32-44.

TORRES, S. (2013), Os jovens no mercado de trabalho: indicadores de medida em confronto (Relatório INE - Estatísticas do Emprego, 2013, 3.0 Trimestre), pp. 35-50. Retrieved from https://ine.pt/xportal/ xmain?xpid=INE\&xpgid=ine_genero_estudo\&m enuBOUI $=13707294 \&$ contexto $=$ pge\&ESTUDOS est_boui $=221756994 \&$ ESTUDOSmodo $=2 \&$ selTa $b=$ tab2\&perfil $=1464373$ \& $x$ lang $=p t$

VALADAS, C. (2013), "Mudanças nas políticas do (des) emprego à empregabilidade", Revista Crítica de Ciências Sociais, (102), pp. 89-110. DOI: 10.1111/ spol. 12290

VIEIRA, M.; V. Ferreira e J. Rowland (2015), "Retrato da juventude em Portugal", Revista Estudos Demográficos, (54), pp. 1-25.

Recebido a 12/08/2017. Aceite para publicação a 20/11/2017.

Mariana Gaio Alves (mga@fct.unl.pt). Universidade Nova de Lisboa, Faculdade de Ciências e Tecnologia, UIED - Unidade de Investigação Educação e Desenvolvimento. Campus de Caparica, 2825-516 Caparica, Portugal.

César Morais (calm@fcsh.unl.pt). Universidade Nova de Lisboa, Faculdade de Ciências Sociais e Humanas, CICS. NOVA - Centro Interdisciplinar de Ciências Sociais. Av. de Berna, 26-C, 1069-061 Lisboa, Portugal.

Miguel Chaves (miguel.chaves@fcsh.unl.pt). Universidade Nova de Lisboa, Faculdade de Ciências Sociais e Humanas, CICS.NOVA - Centro Interdisciplinar de Ciências Sociais. Av. de Berna, 26-C, 1069-061 Lisboa, Portugal. 